\title{
AZ EMBERI VISELKEDÉS ÉPÜLETENERGETIKAI HATÁSAI
}

\section{THE IMPACT OF HUMAN BEHAVIOUR ON BUILDING ENERGY PERFORMANCE}

\author{
Deme Bélafi Zsófia \\ PhD, egyetemi adjunktus \\ Budapesti Műszaki és Gazdaságtudományi Egyetem, Gépészmérnöki Kar Épületgépészeti és Gépészeti Eljárástechnika Tanszék \\ deme@epget.bme.hu
}

\begin{abstract}
ÖSSZEFOGLALÁS
Az épületek az európai végenergia-felhasználás közel harmadáért felelnek, így elengedhetetlen, hogy már a tervezési fázisban is minél pontosabban meg tudjuk határozni energiafogyasztásukat, és azt lehetőség szerint minimálisra csökkentsük.

„Nem az épületek használnak energiát, hanem az emberek." Kathryn B. Janda professzoraszszony az épületeket használó emberek szerepét ezzel az elhíresült mondásával fogalmazta meg 2011-ben.

Kutatásaim során az emberi viselkedést tanulmányozom és számszerűsítem épületenergetikai számításokhoz, szimulációkhoz. Doktori tanulmányaim során az épületek energetikai működésére hatással lévő épülethasználói viselkedéseket vizsgáltam (például: ablakok és árnyékolók nyitása, zárása; a világítás és termosztát használata) több felmérési módszer alapján: érzékelők, kérdőívezés, interjúzás lakókkal és irodai dolgozókkal, környezeti mérőkből kinyert idősoros adatok elemzése, éves energetikai szimulációk.

A 34. Országos Tudományos Diákköri Konferencia Műszaki szekciójában Roska-díjas előadásomban bemutattam a szakterületem, és ismertettem egy nagyszabású nemzetközi kérdőíves projekt eredményeit, amelyben az emberi szokásokat és az azokhoz kapcsolódó döntési folyamatokat, illetve a motivációs szempontokat vizsgáltam egy kutatócsoport tagjaként hat különböző országban.

A projektben két fő kutatási irány képviselői dolgoznak együtt: a szimulációs szoftverek pontosítása érdekében az emberi szokásokat tanulmányozó mérnökök és szoftverfejlesztők, illetve az energiamegtakarításhoz való emberi hozzáállást és viselkedést kutató szociológusok és pszichológusok. Ebben a multidiszciplináris együttmüködésben kimutathatók voltak az egyes országok, kultúrák, klimatikus viszonyok között tapasztalt eltérések és azok energetikai hatásai.
\end{abstract}

\section{ABSTRACT}

Buildings are responsible for nearly one third of end energy consumption in Europe. It is therefore, essential during the design phase of a building to determine its energy consumption as precisely as possible and then decrease it to a minimum level.

'Buildings don't use energy, people do.' Professor Kathryn B Janda defined the role of building users in her famous quote in 2011. 
Throughout my research, I have been studying and quantifying human behaviour to support building energy calculations and simulations. My PhD studies focused on the actions of occupants that might have an impact on a building's energy performance (e.g.: window and shading opening/closing; lighting and thermostat use) by using different sensing and surveying tools: questionnaire, interviews with residents and office workers, time series data analysis obtained from environmental sensors, annual building energy simulations.

In my Roska-prize presentation at the Technical Session of the $34^{\text {th }}$ National Scientific Students' Associations Conference my field of research and the results of a large-scale international questionnaire project were introduced where we studied, as part of a research team, human habits, decision making processes and motivational aspects in six different countries. In this project, researchers participated from two distinct disciplines: on the one hand, engineers and software developers whose aim in occupant behaviour research is to enhance building energy models, and on the other hand, social scientists and psychologists who study human attitudes and behaviour in connection with saving energy. In the framework of this multidisciplinary cooperation, we could show differences between countries, cultures and climates and investigated as well their impact on energy consumption of buildings.

Kulcsszavak: épületenergetika, épülethasználói viselkedés, beltéri komfort, energiafogyasztás

Keywords: building energy, occupant behaviour, indoor comfort, energy consumtion

\section{BEVEZETÉS - A KUTATÁSI TERÜLET BEMUTATÁSA}

Napjainkban a világunk végenergia fogyasztásának 32\%-a épületeinkhez köthetö. Amennyiben csak az elektromos energiára fókuszálunk, ez az arány már 49\%-os (IEA, 2015, 2017). Az épületenergetikai szakterületen dolgozók, illetve az épületeink energiafogyasztását visszaszorítani igyekvő jogalkotók joggal érezhetik a felelösség terhét a vállukon, hiszen minden, az épületállomány jelentős részét érintő kutatási eredmény, illetve jogszabály kiemelkedő hatással lehet a világ energetikai egyensúlyára, közvetve pedig földünk klimatikus viszonyainak alakulására. Egy szomorú jelenség látható a 2010-es években, hogy hiába sikerült épületeink végenergia-fogyasztását négyzetméterenként 1,6\%-kal csökkenteni, az építöipar a növekvő igényeknek csak úgy tud eleget tenni, ha évente 3\%-kal növeli az épületek hasznos alapterületét a világon, vagyis abszolút értékben még mindig növekvő a tendencia.

Hozzávetőlegesen a 19. század végéig az építési kultúrából, illetve a rendelkezésre álló technológiákból egyenesen következett, hogy a belső tereket helyi anyagokkal határolják, a helyi klimatikus viszonyokat figyelembe véve alakítsák ki, valamint a helyben elérhető energiahordozókkal elégítsék ki az épületek energiaigényét. Az épületeket használók pedig alkalmazkodtak ezen körülményekhez. A technológia fejlődésével a múlt évszázadban a tervezők fókusza elcsúszott az emberi igények minél teljesebb kielégítése felé. Sok esetben egy távoli ország- 
ban elérhető technológia segítségével nem megújuló tüzelőanyag felhasználásával igyekeztünk a mind növekvő épülethasználói komfortigényeket kielégíteni a fütés és hütés terén. Mára a fosszilis energiahordozók végességének érzésével megterhelve, újra megváltozott az építészeti, épületgépészeti felfogás: újfent a helyben elérhető megújuló energiaforrások minél hatékonyabb felhasználására helyeződik a hangsúly, ugyanakkor a magas szintű emberi komfortérzet fenntartása alapkövetelmény. Mindez energiahatékony, szelíd technológiákat (kis szürke energia ${ }^{1}$ tartalmú) alkalmazó épületekkel hozható létre, egy értő, tudatos épülethasználót helyezve a középpontba.

Épületeink tervezésekor jelentős figyelmet kell fordítani arra, hogy a használati fázisban azok minél kevesebb energiát fogyasszanak (az egyre szigorodó jogszabályoknak is megfelelve). Ebben a folyamatban ma már elengedhetetlen az éves energiafogyasztás statikus számításokkal és/vagy dinamikus szimulációkkal történő becslése. Az említett becslések segítséget nyújtanak a tervezőknek a kulcsfontosságú építészeti és épületgépészeti döntések meghozatalához (például: a hőszigetelés anyaga, vastagsága, a homlokzatok üvegezési aránya, energiaellátási rendszerek), hogy egy energetikailag is optimális terv tudjon elkészülni.

Az említett becslések pontosságát vizsgálta egy kifejezetten ökologikus és energiatakarékos épületeket középpontba helyező amerikai tanulmány. A kutatók azt vizsgálták, hogy mennyivel tér el az épületek energiafogyasztása a tervezett (számított) és a megvalósult (valós, méréseken alapuló) állapotban.

Az 1. ábrán láthatjuk az egyes épületek két érték közötti szórását. Van, amelyik épület közel háromszor annyit fogyasztott el, mint amennyit a tervezök feltételeztek, de olyan is akadt, amelyik fele annyit.

A kutatók a 2010-es évek elején kezdték el vizsgálni ennek a jelenségnek az okát. A szakterületen mára már konszenzus alakult ki abban, hogy az alábbi tényezők állhatnak a háttérben (Polinder et al., 2013; Yan et al., 2017; Sun-Hong, 2017).

- időjárás,

- emberi viselkedés,

- kivitelezési minőség,

- üzemeltetési paraméterek,

- szimulációs szakember kompetenciája,

- szoftver algoritmusok limitációi.

A fentiek közül számos kutatás az emberi viselkedést emeli ki mint a legnehezebben leírható, megbecsülhető szempontot. Az épülethasználói viselkedésen jelen esetben az emberek komfortpreferenciáját, jelenlétüket, mozgásukat és az

\footnotetext{
${ }^{1}$ Szürke energiának nevezzük azt az energiamennyiséget, amelyet az építőanyagok és az épület előállítása, karbantartása, majd végül bontása, megsemmisítése során használnak fel.
} 


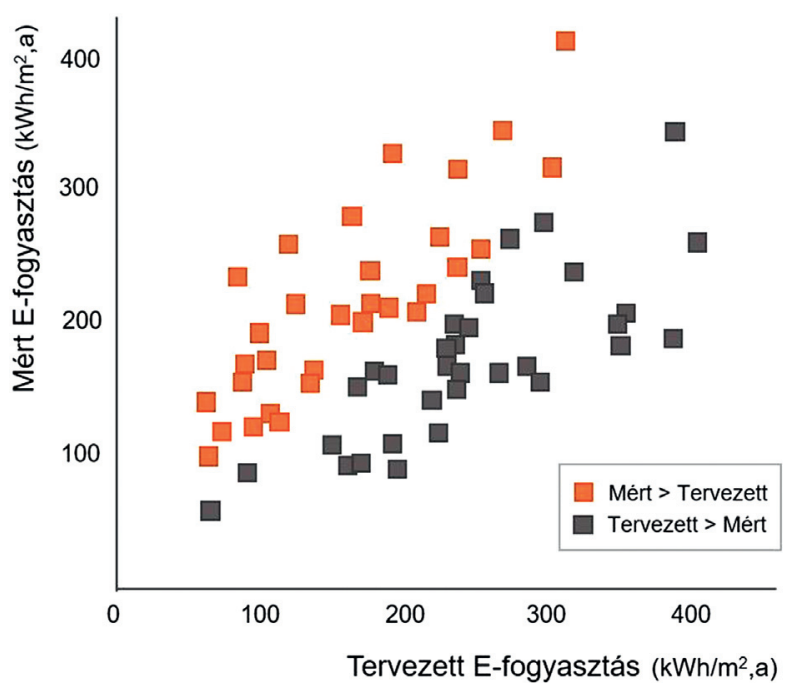

1. ábra. A tervezett és a mért energiafogyasztás viszonya (Turner-Frankel, 2008 adatai alapján)

épület energetikai rendszereibe való adaptív beavatkozásaikat értjük, amelyek mind-mind hatással lehetnek az épület energiafogyasztására és a kialakuló beltéri állapotaira (például: termikus, vizuális, akusztikus komfortszintek, belső levegőminőség).

Azt, hogy önmagában az épületben tartózkodó emberek milyen hatással lehetnek az épület energiafogyasztására, nem egyszerủ számszerüsíteni (mert nehéz kiszürni a többi hatás közül). Egy kutatási projektet hozok példának, ahol véleményem szerint ez mégis sikerült. Egy floridai rehabilitációs projekt részeként épült tíz, építészetileg, szerkezetileg, épületgépészetileg és tájolását tekintve is megegyező lakóház. Az épületeket egy ütemben, egyszerre építették, ugyanazok a kivitelezők. A beköltözést követően ugyanabban az évben mindegyik épületnél energetikai méréseket végeztek. Mivel így a kivitelezési minőség és a klimatikus viszonyok is megegyeztek az egyes épületek esetében, az egyetlen különbség a bent lakók száma és viselkedése lehetett. Az eredmények az éves elektromosenergia-fogyasztásban nem várt különbségeket mutattak. Volt épület, amelyben az ott élő család több mint két és félszer annyi elektromos energiát fogyasztott, mint egy másik épületben élők.

A fent említett eltérések megértéséhez első lépésben az emberi viselkedés vizsgálata szükséges. Az épületekben történő viselkedési vizsgálatok közel harminc éve jelentek meg az épületenergetikai szakirodalomban, föleg a bent tartózkodók termikus és vizuális komfortjához kötődően. A dinamikus épületenergetikai szoftverek megjelenésével a kutatások fókusza a viselkedési trendek leírása és modellezése felé fordult. 


\section{VIZSGÁLATI ESZKÖZÖK A SZAKIRODALOMBAN}

Az épületek energiafogyasztásához köthető leggyakrabban vizsgált viselkedéstípusok az árnyékolók és ablakok nyitása, zárása, illetve a világítás és a termosztát kapcsolása. Az elmúlt tíz évben pedig az egyes műveletek sorrendiségével (preferenciájával) kapcsolatos kutatások is készültek. Az emberi viselkedés vizsgálatára szakterületeink kutatói számos intruzív (a vizsgált alany tisztában van a vizsgálattal, viselkedése esetlegesen megváltozhat), illetve nem intruzív technikát is segítségül hívtak.

Az árnyékolók müködtetésének megfigyelésekor például az árnyékolók aktuális helyzetének rögzítéséből a klimatikus viszonyokkal összevethető idősoros adatbázis képezhető a homlokzatok bizonyos időközönkénti fotózásával vagy az adott információ épületautomatizálási rendszerből való kinyerésével (nem intruzív technikák) (O’Brien et al., 2013).

A lakóépületekben előforduló tevékenységi sorok, mintázatok megfigyelésére alkalmazható például a vizsgálati alanyok nyakába akasztott videókamera (Gauthier-Shipworth, 2015) (intruzív technika), melynek segítségével a kutatók arra a kérdésre keresték a választ, hogy hideg termikuskomfort-érzet esetén az emberek hogyan reagálnak, illetve ha több cselekvést is végrehajtanak (például meleg ital fogyasztása, fütés bekapcsolása, öltözet módosítása), azokat milyen sorrendben teszik. Hasonló kutatások elvégzésére alkalmas egy újonnan kifejlesztett rögzítési mód is, amely nem intruzív technikának számít. Ebben az esetben egy - a gamingből ${ }^{2}$ már ismerős - XBOX Kinectet ${ }^{3}$ használtak a kutatók a lakók múveleti sorrendjének rögzítésére (Dziedzic et al., 2018). A készülék a vevőegységtől méri meg a helyiségben mozgó tárgyak aktuális távolságát, képes felismerni az egyes épülethasználókat, és megfelelő elemzések segítségével személyekhez rendelt tevékenységi sorok hozhatók létre.

A fent említett típusú tanulmányok eredményei hozzájárulnak az épületekben történő emberi viselkedés megértéséhez és leírásához, így épületeink tervezésekor az épületek használóihoz alkalmazkodó épületszerkezeti és -gépészeti rendszerek tervezésével energetikailag lényegesen hatékonyabb épületek jönnek létre.

\section{INTERDISZCIPLINÁRIS KUTATÁS}

Az épületekben előforduló emberi tevékenységekkel számos szakterület foglalkozik. Amennyiben a felhasználó múvelete közvetett vagy közvetlen hatással van az épület energiafogyasztására, az épületgépészeti, építészeti szakterületekre van

${ }^{2}$ Videójátékok.

${ }^{3}$ Speciális mozgásérzékelő eszköz videójátékokhoz. 
szükség. Az emberi viselkedés leírásához, modellezéséhez, későbbi szoftverintegrációjához pedig adatbányászok, modellezők és informatikusok bekapcsolódása szükséges.

Azonban a végső műveletek (ablaknyitás vagy termosztátállítás) megértéséhez és számszerüsítéséhez elengedhetetlen, hogy az emberi agyra ható külső és belső tényezőket is megvizsgáljuk. Ugyanilyen fontos az is, hogy megértsük, az egyes egyének milyen szociológiai kontextusban léteznek, milyen helyet foglalnak el az emberek csoportjában (például: többfös család részeként vagy többszemélyes irodákban). Ezt követi az emberi agy döntéshozási mechanizmusainak kutatása. Ezekből a szempontokból a szakterület fejlődésével pszichológusok, orvosok és szociológusok kezdtek el foglalkozni.

A 2. ábrán a doktori tanulmányaim során kidolgozott rendszerleírás látható, amelyben a kutatásaimkor vizsgált egyes lépések láthatók a hozzájuk tartozó szakterületek megjelölésével.

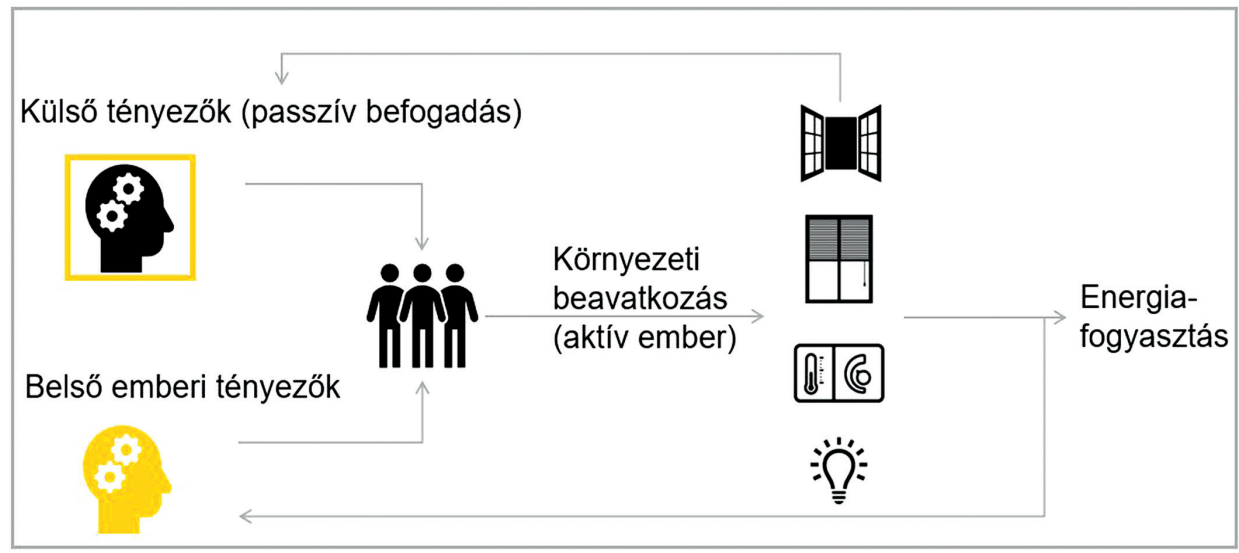

Szociológia, komfort tudományok

\section{Épületenergetika, építészet, épületüzemeltetés}

2. ábra. Az emberi viselkedés kutatási rendszere az épületenergetikában

(Deme Bélafi, 2018)

Meggyőződésem, hogy a szakterületünk fejlődéséhez a jövőben elengedhetetlen lesz az egyes témákban tevékenykedő tudományágak interdiszciplináris kutatási projektekben történő együttmüködése. A doktori kutatásaim során szerencsém volt több ilyen típusú projektbe is bekapcsolódni. Az alábbiakban a Nemzetközi 
Energia Ügynökség (IEA) által összefogott ANNEX66 projektben (Yan et al., 2017) létrejött gépészmérnököket, szoftverfejlesztőket, építészmérnököket és szociológusokat összefogó kutatást mutatom be.

\section{NEMZETKÖZI IRODAHASZNÁLATI FELMÉRÉS}

A kutatásban az emberek és az épületek kölcsönhatását vizsgáltuk irodaépületek esetében hat különböző országban: Brazília, Olaszország, Lengyelország, Svájc, Amerikai Egyesült Államok és Tajvan.

\subsection{A felmérés fö céljai}

- Az egyes vizsgált országok között tapasztalható különbségek kimutatása az épülethasználók adaptív termikus komfort visszaállítását szolgáló műveleteiben, illetve a csoportos viselkedésben, a csoport normáihoz való alkalmazkodásban.

- Az egyes felmért viselkedési mintázatok összefüggéseinek, sorrendiségének és motiváló tényezőinek vizsgálata szociológiai, pszichológiai, demográfiai paraméterekkel és az épület fizikai környezetével.

- Az épületek energiahatékonyságát biztosító rendszerek használói szociológiai és pszichológiai hátterének vizsgálata (például: csoportos viselkedés), amely lehetővé tenné nemcsak a fizikai paraméterek szimulációját energiamodelljeinkben, hanem a szociális kontextusét is.

\subsection{Módszertan}

A kutatás kezdeti fázisában három kollégámmal (szociológus, építészmérnök, épületgépész mérnök) kifejlesztettünk egy multidiszciplináris kutatási keretrendszert, amelyben meghatároztuk a kutatás céljainak eléréséhez szükséges felmérendő paramétereket, illetve az egyes változók feltételezett összefüggéseit (D’Oca et al., 2017). Ezt követően összeállítottunk egy harminchét kérdésből álló transzverzális (vagyis egy időpillanatban, nagy mintaszámban felvett) kérdőivet, amelynek segítségével egyrészt azon szociológiai, pszichológiai és demográfiai szempontokat (független változók) tudtuk felmérni, amelyek hatással lehetnek az épülethasználók viselkedésére, például úgy, mint a szabályozási opciók megosztására való hajlandóság (függő változók). Másrészt, be tudtuk azonosítani, hogy egy csoport tagjaként a felhasználó milyen szabályozási lehetőséget választ a felmért független változókkal összevetve.

A kérdőív kitöltői tizennyolc éven felüli egyetemi és kutatóintézeti irodákban dolgozók közül kerültek ki - az adattisztítást követően - 3472 mintaszámmal (Brazília $=252$, Olaszország $=728$, Lengyelország $=715$, Svájc $=191$, USA $=1306$, Tajvan $=280$ ). 
A kérdöívben minden kérdés egy vagy több független változót képvisel, hogy meg tudjuk mérni a kutatás kérdéses paramétereit. A személyiségi jogok megsértése nélkül leszürhető továbbá a válaszokból az épület helye és a kitöltés időpontja (klimatikus viszonyok) mint további paraméterek. Minden kutatási paramétert a válaszadók becsültek meg előre definiált, diszkrét értékekből álló, valamint ötfokú Likert-skálán.

Az adatgyüjtés időszaka a 2017/18-as tanév volt. Ezt követte az adattisztítás fázisa. Az adatelemzés és modellezés a végleges adatbázison az SPSS szoftverben készült, ahol a függő és független változók kapcsolatának vizsgálata lineáris regresszióval történt meg. Ezt követően a további elemzések elkészítéséhez kétváltozós logisztikus regressziót, ANOVA- és Chi-négyzet teszteket használtunk.

\subsection{Eredmények és diszkusszió}

Az alábbiakban a kutatás legfontosabb eredményeit ismertetem. Mind a kutatás hátteréről, módszertanáról, mind a részletes eredményekről kutatócsoportunk egy nemrég megjelent folyóiratcikkben számol be (Chen et al., 2019).

Az épület fizikai környezete és a felhasználók számára elérhető beavatkozási lehetőségek vizsgálatából kiderült, hogy minden országban az irodák többsége (62-93\%) többszemélyes kialakítású (3. ábra). A legtöbb irodában elérhető beavatkozási opció a világítás kapcsolása. A nyitható ablakok, illetve a hütés/fütés szabályozására használt termosztát elérhetősége nagy eltéréseket mutat: például az USA-ban mindössze a válaszadók 23\%-ának van hozzáférése nyitható ablakhoz és mindössze $28 \%$-nak termosztáthoz. A legtöbb szabályozási lehetőségük a Brazíliában és az európai országokban élőknek van.

Az egyik kulcsfontosságú felfedezés, hogy a válaszadók többsége az épület aktív, energiafogyasztó komfortgépészete helyett a passzívnak nevezett, személyes müveleteket részesíti előnyben, például az öltözet módosítását. Ezek a műveletek jelenleg az épületek tervezési fázisában az épületenergetikai számításokból, szimulációkból teljes mértékben hiányoznak.

A többszemélyes irodák esetében megvizsgáltuk, hogy a csoportos viselkedés különbözik-e az egyszemélyes irodákban tapasztaltaktól; valamint azt is, hogy melyek azok a tényezők, amelyek befolyásolják az egyes felhasználók alkalmazkodási hajlandóságát a többiek akaratához. Az eredmények azt mutatták, hogy az alkalmazkodás pozitív elörejelzője a felhasználó pozitív attitűdje, a magas érzékelt környezeti kontroll, az erős fogékonyság a szociális normák betartására, az általában tapasztalt jó beltéri környezeti minőség (IEQ), és ha úgy gondolja, hogy az IEQ jó hatással van a produktivitásra. A környezeti beavatkozási opciókra vonatkozó tudást az adatok nem mutatták relevánsnak. Demográfiai szempontból a nők és fiatalok mutatkoztak alkalmazkodóbbaknak. 


\begin{tabular}{|c|c|c|c|c|c|c|c|}
\hline & & صِّ & 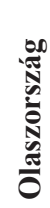 & 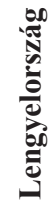 & 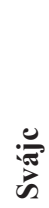 & 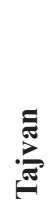 & $\underset{\mathscr{D}}{\mathscr{D}}$ \\
\hline & & \multicolumn{6}{|c|}{$\%$} \\
\hline inin & Többszemélyes irodák aránya & 86 & 68 & 81 & 83 & 93 & 62 \\
\hline 田田 & Ablaknyitás & 91 & 90 & 85 & 69 & 64 & 24 \\
\hline 車 & Árnyékoló & 82 & 78 & 79 & 77 & 66 & 54 \\
\hline 迆回 & Termosztát & 77 & 67 & 66 & 57 & 63 & 28 \\
\hline 沉: & Világítás & 96 & 99 & 98 & 95 & 83 & 81 \\
\hline
\end{tabular}

3. ábra. Az irodaépületek típusai és a felhasználók beavatkozási opciói (Chen et al., 2019 adatai alapján)

A nyári termikus diszkomfort hatására bekövetkező emberi tevékenységek sorrendjével kapcsolatban az alábbi eredmények születtek. Elsőként a ruházaton állítanak, ezt követi az ablaknyitás, majd a hideg üdítő fogyasztása, és csak ezeket követően történik meg a termosztát szabályozása, a hütési rendszer bekapcsolása. Természetesen ehhez a teljes mintára elkészült sorrendhez képest kisebb eltérések tapasztalhatók az egyes országok között, részben a klimatikus, részben a kulturális különbségek miatt.

\section{5. ÖSSZEFOGLALÁS}

A fent bemutatott projekt eredményei, illetve szakterületünk számos kutatása kimutatta, hogy a felhasználókhoz köthető szociológiai és pszichológiai paraméterek, valamint az épületek fizikai környezete egyformán fontos paraméterek az emberek és az épületek közötti, energetikához köthető müveletek, illetve a csoportos viselkedés leírásában.

Az épületeket használó emberek megismerése és viselkedésük leírása, modellezése elengedhetetlen ahhoz, hogy épületeink használati fázisában biztosítani tudjuk a minél alacsonyabb energiafogyasztást az elvárt beltéri komfortszintek 
fenntartása mellett. Ezen paraméterek figyelembevétele, illetve jövőbeli beépítése az épületek tervezési fázisa során elvégzett számításokba és szimulációkba, kulcsfontosságú lesz ahhoz, hogy az épületeink energiafogyasztását a lehető leghatékonyabban tudjuk csökkenteni.

\section{KÖSZÖNETNYILVÁNÍTÁS}

A kutatás első fázisában lezajlott kutatói cserét a Fulbright Magyar-Amerikai Oktatási Csereprogram támogatta. A kutatás az Emberi Erőforrások Minisztériuma ÚNKP-17-3-I. kódszámú Új Nemzeti Kiválóság Programjának támogatásával készült. A szerző ezúton is köszönetet mond az OTDT-nek a 34. OTDK Műszaki Szekcióban odaítélt Roska Tamás díjért.

\section{IRODALOM}

Chen, C. - Hong, T. - Xu, X. et al. (2019): Culture, Conformity, and Carbon? A Multi-Country Analysis of Heating and Cooling Practices in Office Buildings. Energy Research and Social Science, 61, https://bit.ly/34m4N3Z

Deme Bélafi Zs. (2018): Analysis and Modelling of Occupant Behaviour to Support Building Design and Performance Optimisation (PhD Thesis). Budapest University of Technology and Economics, https://repozitorium.omikk.bme.hu/bitstream/handle/10890/5501/ertekezes. pdf? sequence $=2 \&$ isAllowed $=y$

D’Oca, S. - Chen, C. - Hong, T. et al. (2017): Synthesizing Building Physics with Social Psychology: An Interdisciplinary Framework for Context and Behavior in Office Buildings. Energy Research and Social Science, 34, July, 240-251. DOI: 10.1016/j.erss.2017.08.002, https://eta.lbl. gov/publications/synthesizing-building-physics-social

Dziedzic, J. - Yan, D. - Novakovic, V. (2018): Indoor Occupant Behaviour Monitoring with the Use of a Depth Registration Camera. Building and Environment, 148, 44-54. https://www. researchgate.net/publication/328406411_Indoor_occupant_behaviour_monitoring_with_the use_of_a_depth_registration_camera

Gauthier, S. - Shipworth, D. (2015): Behavioural Responses To Cold Thermal Discomfort. Building Research \& Information, 45, 3, DOI: 10.1080/09613218.2015.1003277, https://discovery.ucl. ac.uk/id/eprint/1461295/1/Gauthier.Shipworth_2015.pdf

IEA (2015): Energy Efficiency Market Report 2015: Market Trends and Medium-Term Prospects. Paris. IEA, http://www.ieadsm.org/wp/files/2015_Energy_Efficiency_Market_Report.pdf

IEA (2017): World Energy Outlook 2017. Paris: IEA,--https://www.iea.org/reports/worldenergy-outlook-2017

O’Brien, W. - Kapsis, K. - Athienitis, A. K. (2013): Manually-operated Window Shade Patterns in Office Buildings: A Critical Review. Building and Environment, 60, 319-338. DOI: 10.1016/j. buildenv.2012.10.003

Polinder, H. - Schweiker, M. - Aa, A. Van Der et al. (2013): Final Report Annex 53. Vol. 2. Occupant Behavior and Modeling. http://www.iea-ebc.org/Data/publications/EBC_Annex_53_Appendix_Volume_2.pdf 
Sun, K. - Hong, T. (2017): A Framework for Quantifying the Impact of Occupant Behavior on Energy Savings of Energy Conservation Measures. Energy and Buildings, 146, 383-396. DOI: 10.1016/j.enbuild.2017.04.065, https://escholarship.org/uc/item/1n93z81r

Turner, C. - Frankel, M. (2008): Energy Performance of LEED ${ }^{\circledR}$ for New Construction Buildings. New Buildings Institute, 1-46. https://newbuildings.org/sites/default/files/Energy_Performance_of_LEED-NC_Buildings-Final_3-4-08b.pdf

Yan, D. - Hong, T. - Dong, B. et al. (2017): IEA EBC Annex 66: Definition and Simulation of Occupant Behavior in Buildings. Energy and Buildings, 156, 258-270. DOI: 10.1016/j.enbuild.2017.09.084, https://www.researchgate.net/publication/274954468_IEA_EBC_Annex_ 66_Definition_and_Simulation_of_Occupant_Behavior_in_Buildings 